Aspirasi: Jurnal Masalah-Masalah Sosial | Volume 10, No. 1 Juni 2019

ISSN: 2086-6305 (print) ISSN: 2614-5863 (electronic)

DOI: https://doi.org/10.22212/aspirasi.v7il.1084

link online: http://jurnal.dpr.go.id/index.php/aspirasi/index

\title{
PENINGKATAN KUALITAS PENDIDIKAN: PROGRAM PENDIDIKAN PROFESI GURU PRAJABATAN DALAM PEMENUHAN KEBUTUHAN GURU PROFESIONAL DI INDONESIA
}

\author{
Improvement of Education Quality: Pre-service Teacher Professional Education \\ Programs in Meeting the Needs of Professional Teachers in Indonesia
}

Fieka Nurul Arifa, Ujianto Singgih Prayitno

\author{
fiekanarifa@gmail.com \\ Pusat Penelitian Badan Keahlian DPR RI \\ Jl. Gatot Subroto, Senayan, Jakarta
}

Naskah Diterima: 29 Maret 2019 | Naskah direvisi: 10 Juni 2019| Naskah diterbitkan: 29 Juni 2019

\begin{abstract}
The quality of education of a nation is determined by the quality of educators. Teachers as implementers of education at the basic, secondary and early age levels must have competencies and qualifications that meet national education standards. The Pre-service Teacher Professional Education Programs is a breakthrough to prepare certified professional teacher candidates. Teacher's requirements for academic qualifications are at least bachelor and must also have an educator certificate obtained through a certification program. With the end of certification through Teacher Professional Education and Training Programs, the entire certification process is taken through Teacher Professional Education Programs. This study uses a qualitative approach with library research method to find out ways in which the Pre-service Teacher Professional Education Programs policy meet the needs of professional teachers in Indonesia. In the implementation of Pre-service Teacher Professional Education Programs, there are still some challenges, namely: (1) the quality of Educational Personnel Education Institution, (2) the qualifications of prospective students, and (3) distribution of graduates. There needs to be improvements in terms of governance and regulation to improve the effectiveness of the Pre-service Teacher Professional Education Programs.
\end{abstract}

Keywords: quality of education, professional teacher, Pre-service Teacher Professional Education Programs.

Abstrak: Kualitas pendidikan suatu bangsa ditentukan oleh kualitas pendidik. Guru sebagai pelaksana pendidikan pada jenjang dasar, menengah dan usia dini harus memiliki kompetensi dan kualifikasi yang memenuhi standar nasional pendidikan. Program Pendidikan Profesi Guru Prajabatan merupakan terobosan untuk menyiapkan calon guru profesional yang telah tersertifikasi. Persyaratan kualifikasi akademik guru setidaknya S-1 dan harus memiliki sertifikat pendidik yang diperoleh melalui program sertifikasi. Dengan berakhirnya sertifikasi melalui Program Pendidikan dan Latihan Profesi Guru maka seluruh proses sertifikasi ditempuh melalui Pendidikan Profesi Guru. Kajian ini menggunakan pendekatan kualitatif dengan metode kepustakaan (library research) untuk mengetahui bagaimana kebijakan Pendidikan Profesi Guru Prajabatan dalam pemenuhan kebutuhan guru profesional di Indonesia. Dalam pelaksanaannya Pendidikan Profesi Guru Prajabatan masih terkendala: (1) kualitas Lembaga Pendidikan Tenaga Kependidikan, (2) kualifikasi calon peserta didik, dan (3) penyerapan lulusan. Perlu adanya perbaikan dari sisi tata kelola dan regulasi guna meningkatkan efektivitas penyelenggaraan Pendidikan Profesi Guru Prajabatan.

Kata kunci: kualitas pendidikan, guru profesional, Pendidikan Profesi Guru Prajabatan.

Fieka Nurul Arifa \& Ujianta Singgih Prayitna Peningkatan Kualitas Pendidikan: Pragram Pendidikan. 


\section{Pendahuluan}

Persoalan pendidikan yang dihadapi oleh Indonesia saat ini, bukan lagi hanya mengupayakan pendidikan yang dapat diakses (accessible) oleh setiap warga negaranya, tetapi juga membenahi kualitas pendidikannya (Gaol, 2018), karena kualitas pendidikan menentukan kualitas sumber daya manusia, yang berkorelasi dengan peradaban bangsa Indonesia di masa mendatang. Berdasarkan data Global Human Capital Report yang diterbitkan World Economic Forum pada tahun 2017, peringkat Indonesia dalam bidang pendidikan menempati peringkat 65 dari 130 negara. Pada posisi tersebut, Indonesia masih jauh tertinggal dari negara-negara anggota ASEAN, misalnya Singapura yang berada pada urutan 12, Malaysia pada urutan 33, Thailand pada urutan 40 dan Filipina pada urutan ke 50 (Gaol, 2018).

Secara nasional prestasi siswa diantaranya dapat dilihat pada hasil Ujian Nasional (UN) dan Indonesia National Assessment Program (INAP), sementara dalam skala internasional prestasi siswa dapat dilihat dari pencapaian Programme for International Student Assessment (PISA) dan Trends in International Mathematics and Science Study (TIMSS). Rerata nilai Ujian Nasional (UN) SMP terus mengalami penurunan. Tabel 1. menunjukkan bahwa nilai UN pada jenjang SMP/ MTs, SMA/MA, serta SMK terus mengalami penurunan dari tahun 2014/2015 sampai dengan $2018 / 2019$. Salah satu faktor yang mempengaruhi penurunan nilai UN berasal dari guru.

Tabel 1. Rata-Rata nilai UN

\begin{tabular}{llll}
\hline \multicolumn{1}{c}{$\begin{array}{c}\text { Tahun } \\
\text { Ajaran }\end{array}$} & \multicolumn{3}{c}{ Jenjang Pendidikan } \\
\hline Januari & SMP/MTs & SMA/MA & SMK \\
$2015 / 2016$ & 61,81 & 58,27 & 62,15 \\
$2016 / 2017$ & 58,61 & 53,86 & 58,54 \\
$2017 / 2018$ & 54,25 & 50,10 & 53,75 \\
$2018 / 2019$ & 51,10 & 50,80 & 45,21 \\
\hline
\end{tabular}

Sumber: https://puspendik.kemdikbud.go.id/hasil-un/.

Capaian kemampuan literasi membaca, numerasi, dan sains anak Indonesia masih rendah (Adzkia, 2018). Hal tersebut diantaranya didukung oleh pencapaian hasil INAP, PISA, dan TIMSS. Data INAP Balitbang Kemendikbud yang dilakukan pada tahun 2016 menunjukkan bahwa pencapaian siswa dominan pada kategori kurang. Secara berturut-turut persentase penguasaan matematika, membaca dan sains yang termasuk dalam kategori kurang secara berturutturut sebesar $77,13 \%, 44,83 \%$ dan $73,61 \%$. Sementara yang termasuk dalam kategori baik adalah 2,29\%, 6,06\%, dan 1,01\%. Sisanya, berada dalam kategori cukup ("Hasil Indonesian National Assesment Programme (INAP)", 2016).

Secara global hasil PISA 2015 memposisikan Indonesia pada urutan ke 62 dari 70 negara (OECD, 2016:4). Sementara hasil TIMSS 2015, Indonesia berada di urutan 44 dari 49 negara dalam kemampuan matematika (Mullis, Martin, Foy, \& Arora, 2015: 12) dan berada pada posisi ke 44 dari 47 negara dalam kemampuan sains (Martin, Mullis, Foy, \& Hooper, 2015: 12). Rendahnya pencapaian prestasi siswa menunjukkan bahwa kinerja guru masih perlu diperbaiki. Selain itu, data UNESCO dalam Global Education Monitoring (GEM) Report 2016, mutu pendidikan di Indonesia hanya menempati peringkat ke-10 dari 14 negara berkembang (Yunus, 2018).

Saat ini, upaya untuk meningkatkan mutu pendidikan menghadapi kendala yang cukup serius, mengingat saat ini evaluasi belajar akhir nasional tidak lagi ditentukan oleh Ujian Nasional, tetapi sepenuhnya ditentukan oleh sekolah dan guru. Sementara data UNESCO menyebutkan bahwa kualitas guru sebagai komponen penting dalam pendidikan, berada di urutan ke-14 dari 14 negara berkembang di dunia (Yunus, 2018). Oleh karena itu, guru profesional merupakan kunci peningkatan mutu pendidikan yang mendorong kemajuan suatu bangsa.

Sebagai pelaksana pendidikan guru memegang peranan penting untuk mencerdaskan dan mengantarkan anak bangsa menyongsong masa depan yang cerah. Dalam melaksanakan peran tersebut profesionalisme menjadi syarat utama yang dibutuhkan. Seorang guru dapat dikatakan profesional jika dia memenuhi kualifikasi serta kompetensi sesuai standar. Karena kompetensi guru merupakan modal 
utama untuk menciptakan pembelajaran yang berkualitas. Guru yang berkompeten mampu menyampaikan pembelajaran yang bermutu dan selalu berupaya menciptakan suasana belajar yang kondusif dengan memanfaatkan segala sesuatu yang dapat digunakan sebagai sumber belajar serta meminimalisir keterbatasan dan hambatan.

Mengingat pentingnya guru dalam upaya meningkatkan kualitas pendidikan, maka guru perlu dipersiapkan sedemikian rupa untuk menjadi guru yang profesional, yang salah satu cara yang dapat ditempuh adalah melalui Program Pendidikan Profesi Guru (PPG) Prajabatan. Salah satu upaya pemerintah dalam pemenuhan guru profesional dilakukan dengan memperketat sistem rekrutmen guru. Pemerintah daerah tidak diperbolehkan merekrut guru honorer khususnya bagi sekolah negeri. Perekrutan guru honorer yang dilakukan melalui Surat Keputusan Kepala Sekolah dinilai melanggar Peraturan Pemerintah No. 48 Tahun 2005 Jo Peraturan Pemerintah No 43 Tahun 2007. Saat ini pemerintah memprioritaskan pemenuhan guru profesional melalui rekrutmen Calon Pegawai Negeri Sipil (CPNS) dan Pegawai Pemerintah dengan Perjanjian Kerja (PPPK) dengan sistem rekrutmen yang dilakukan secara profesional. Hal tersebut tentu merupakan kebijakan yang tepat agar kualitas guru dapat terpantau dan terukur. Namun demikian, tingginya kebutuhan sekolah terhadap pemenuhan pengajar dan banyaknya lulusan sarjana pendidikan menjadikan sekolah mengangkat sarjana mengajar atau yang lazim disebut guru tidak tetap (GTT) untuk memenuhi kebutuhan yang mendesak.

Kondisi tersebut menuntut perbaikan tata kelola pendidikan melalui sistem rekrutmen yang memenuhi standar. Semestinya, calon guru yang dapat mengikuti seleksi adalah calon guru yang telah memenuhi kualifikasi guru profesional. Program Profesi Guru (PPG) Prajabatan merupakan langkah yang dinilai dapat menghadirkan calon-calon guru profesional yang siap mengabdi dan meningkatkan kualitas pendidikan. Calon-calon ini pula diharapkan nantinya dapat mengisi kekosongan guru akibat banyaknya guru yang pensiun. Namun demikian, penyelenggaraan PPG masih terus memerlukan perbaikan.

Tulisan bertujuan untuk mengetahui tentang kebijakan PPG Prajabatan serta bagaimana implikasinya dalam pemenuhan guru profesional. Adapun permasalahan dalam tulisan ini dirumuskan dengan: bagaimana PPG Prajabatan dalam pemenuhan kebutuhan guru profesional di Indonesia? Tulisan ini diharapkan dapat turut memberikan kontribusi terhadap kajian mengenai peningkatan profesionalisme guru. Pendekatan yang digunakan dalam penelitian ini adalah pendekatan kualitatif dengan metode kepustakaan (library research). Data dalam penelitian ini berasal dari berbagai sumber baik cetak maupun online serta hasil penelitian yang relevan.

\section{Kualifikasi Akademik Guru}

Standar Nasional Pendidikan (SNP) mensyaratkan bahwa kualifikasi akademik guru harus berpendidikan minimal strata satu (S-1). Sementara Undang-undang No. 14 Tahun 2005 tentang Guru dan Dosen (UUGD) Pasal 82 Ayat 2 memberikan ketentuan bahwa guru yang belum memiliki kualifikasi akademik dan belum memiliki sertifikat pendidik wajib memenuhi kualifikasi akademik dan memperoleh sertifikat pendidik paling lama 10 (sepuluh) tahun sejak diberlakukannya UUGD. Jika amanat mengenai kewajiban pemenuhan kualifikasi pendidikan dan sertifikasi sebagaimana termaktub dalam UUGD terealisasi maka seharusnya pada 2019 tidak ada lagi guru yang belum berpendidikan S-1 dan semua guru di Indonesia telah memiliki sertifikat pendidik.

Data jumlah guru di Indonesia per Desember 2017 yang dipaparkan Kemendikbud RI pada 16 Januari 2018, menyatakan bahwa jumlah guru saat ini lebih dari 3 juta orang. Data tersebut menunjukkan masih banyak guru yang belum memenuhi syarat kualifikasi akademik, dan banyak pula guru belum memiliki sertifikat profesi. Di sisi lain, seorang guru dalam menjalankan tugasnya harus memiliki standar kompetensi yang mencakup kompetensi 
Tabel 2. Rincian Jumlah Guru Nasional

\begin{tabular}{|c|c|c|c|c|c|c|c|c|c|c|c|c|c|c|c|}
\hline \multirow{3}{*}{$\begin{array}{c}\text { Jenjang } \\
\text { dan } \\
\text { Status } \\
\text { Sekolah }\end{array}$} & \multicolumn{7}{|c|}{ Bukan PNS } & \multicolumn{7}{|c|}{ PNS } & \multirow{3}{*}{$\begin{array}{c}\text { Jumlal } \\
\text { Bukan } \\
\text { PNS \& } \\
\text { PNS }\end{array}$} \\
\hline & \multicolumn{3}{|c|}{ Belum Sertifikasi } & \multicolumn{3}{|c|}{ Sudah Sertifikasi } & \multirow{2}{*}{ Jml } & \multicolumn{3}{|c|}{ Belum Sertifikasi } & \multicolumn{3}{|c|}{ Sudah Sertifikasi } & \multirow{2}{*}{ Jml } & \\
\hline & $\begin{array}{c}\text { Belum } \\
\text { S-1 }\end{array}$ & $\begin{array}{c}\text { Sudah } \\
\text { S-1 }\end{array}$ & $\mathrm{Jml}$ & $\begin{array}{c}\text { Belum } \\
\text { S-1 }\end{array}$ & Sudah S-1 & $\mathbf{J m l}$ & & $\begin{array}{c}\text { Belum } \\
\text { S-1 }\end{array}$ & $\begin{array}{c}\text { Sudah } \\
\text { S-1 }\end{array}$ & Jumlah & $\begin{array}{c}\text { Belum } \\
\text { S-1 }\end{array}$ & $\begin{array}{c}\text { Sudah } \\
\text { S-1 }\end{array}$ & Jumlah & & \\
\hline \multicolumn{16}{|l|}{ NEGERI } \\
\hline SD & 125334 & 330564 & 455898 & 184 & 9176 & 9360 & 465258 & 71367 & 103679 & 175046 & 65966 & 582706 & 648672 & 823718 & 1288976 \\
\hline SDLB & 93 & 308 & 401 & & 12 & 12 & 413 & 55 & 114 & 169 & 89 & 603 & 692 & 861 & 1274 \\
\hline SLB & 674 & 2472 & 3146 & 1 & 88 & 89 & 3235 & 217 & 1016 & 1233 & 178 & 3429 & 3607 & 4840 & 8075 \\
\hline SMA & 2432 & 61540 & 63972 & 11 & 1791 & 1802 & 65774 & 640 & 27510 & 28150 & 1347 & 116652 & 117999 & 146149 & 211923 \\
\hline SMK & 3586 & 45870 & 49456 & 10 & 1382 & 1392 & 50848 & 600 & 21420 & 22020 & 663 & 61625 & 62288 & 84308 & 135156 \\
\hline SMLB & 8 & 59 & 67 & & & 0 & 67 & 3 & 13 & 16 & & 18 & 18 & 34 & 101 \\
\hline SMP & 13192 & 125296 & 138488 & 44 & 3355 & 3399 & 141887 & 6167 & 48220 & 54387 & 136523 & 242388 & 378911 & 433298 & 575185 \\
\hline SMPLB & 10 & 68 & 78 & & 5 & 5 & 83 & 2 & 17 & 19 & 2 & 47 & 49 & 68 & 151 \\
\hline $\begin{array}{l}\text { Jumlah } \\
\text { Negeri }\end{array}$ & 4138 & 569887 & 719354 & 262 & 16209 & 16471 & 735825 & 80379 & 203433 & 283812 & 205112 & 1013016 & 1218128 & 1501940 & 2237765 \\
\hline \multicolumn{16}{|l|}{ SWASTA } \\
\hline SD & 29509 & 85041 & 114550 & 963 & 37045 & 38008 & 152558 & 6045 & 3981 & 10026 & 2819 & 11219 & 14038 & 24064 & 176622 \\
\hline SDLB & 205 & 344 & 549 & 5 & 160 & 165 & 714 & 10 & 18 & 28 & 5 & 261 & 266 & 294 & 1008 \\
\hline SLB & 2450 & 5156 & 7606 & 27 & 1822 & 1849 & 9455 & 88 & 161 & 249 & 128 & 4072 & 4200 & 4449 & 13904 \\
\hline SMA & 5696 & 49327 & 55023 & 183 & 23530 & 23713 & 78736 & 130 & 1801 & 1931 & 195 & 7608 & 7803 & 9734 & 88470 \\
\hline SMK & 16658 & 96078 & 112736 & 279 & 33731 & 34010 & 146746 & 301 & 2214 & 2515 & 127 & 6568 & 6695 & 9210 & 155956 \\
\hline SMLB & 69 & 143 & 212 & & 48 & 48 & 260 & & 5 & 5 & & 55 & 55 & 60 & 320 \\
\hline SMP & 22656 & 89512 & 112168 & 782 & 39903 & 40685 & 152853 & 670 & 2235 & 2905 & 1083 & 9368 & 10451 & 13356 & 166209 \\
\hline SMPLB & 73 & 256 & 329 & & 60 & 60 & 389 & 5 & 10 & 15 & & 109 & 109 & 124 & 513 \\
\hline TK & 112641 & 81085 & 193726 & 2261 & 60508 & 62769 & 256495 & 4497 & 2905 & 7402 & 3379 & 32253 & 35632 & 43034 & 299529 \\
\hline $\begin{array}{l}\text { Jumlah } \\
\text { Swasta }\end{array}$ & 189957 & 406942 & 596899 & 4500 & 196807 & 201307 & 798206 & 11746 & 13330 & 25076 & 7736 & 71513 & 79249 & 104325 & 902531 \\
\hline SDLB & 298 & 652 & 950 & 5 & 172 & 177 & 1127 & 65 & 132 & 197 & 94 & 864 & 958 & 1155 & 2282 \\
\hline SLB & 3124 & 7628 & 10752 & 28 & 1910 & 1938 & 12690 & 305 & 1177 & 1482 & 306 & 7501 & 7807 & 9289 & 21979 \\
\hline SMA & 8128 & 110867 & 118995 & 194 & 25321 & 25515 & 144510 & 770 & 29311 & 30081 & 1542 & 124260 & 125802 & 155883 & 300393 \\
\hline SMK & 20244 & 141948 & 162192 & 289 & 35113 & 35402 & 197594 & 901 & 23634 & 24535 & 790 & 68193 & 68983 & 93518 & 291112 \\
\hline SMLB & 77 & 202 & 279 & 0 & 48 & 48 & 327 & 3 & 18 & 21 & 0 & 73 & 73 & 94 & 421 \\
\hline SMP & 35848 & 214808 & 250656 & 826 & 43258 & 44084 & 294740 & 6837 & 50455 & 57292 & 14606 & 251756 & 266362 & 323654 & 618394 \\
\hline SMPLB & 83 & 324 & 407 & 0 & 65 & 65 & 472 & 7 & 27 & 34 & 2 & 156 & 158 & 192 & 664 \\
\hline TK & 116779 & 84795 & 201574 & 2273 & 60908 & 63181 & 264755 & 5825 & 4349 & 10174 & 3723 & 37801 & 41524 & 51698 & 316453 \\
\hline $\begin{array}{l}\text { Jumlah } \\
\text { Negeri \& } \\
\text { Swasta }\end{array}$ & 339424 & 976829 & 1316253 & 4762 & 213016 & 217778 & 1534031 & 92125 & 216763 & 308888 & 89848 & 1084529 & 1174377 & 1483265 & 3017296 \\
\hline
\end{tabular}

Sumber: Paparan Mendikbud RI pada Raker dengan Komisi X DPR RI, 16 Januari 2018

pedagogik, kepribadian, sosial, dan profesional.

Kondisi guru di Indonesia saat ini masih berada jauh di bawah target capaian yang tercantum dalam amanat UUGD, baik dari sisi kualifikasi pendidikan maupun kompetensi. Tabel 2 menunjukkan rincian jumlah guru nasional berdasarkan status sekolah, jenjang sekolah, status S-1, status sertifikasi, dan status PNS yang belum termasuk guru agama di dalamnya. Dari sisi kualifikasi pendidikan, berdasarkan Tabel 2. saat ini masih terdapat 525.159 orang $(17,44 \%)$ guru dalam jabatan yang belum memenuhi kualifikasi akademik S-1, sementara guru yang belum sertifikasi saat ini sebanyak 1.625.141 orang guru $(53,86 \%)$ dari total guru di Indonesia yang berjumlah 3.017.296 guru (Kemendikbud, 2018: 27). Hal tersebut menunjukkan bahwa jumlah guru yang belum tersertifikasi lebih banyak dari jumlah guru yang telah tersertifikasi.

Dari sisi prestasi dan kinerja, kualitas guru yang belum memadai yang ditandai dengan: pertama, rendahnya pencapaian Uji Kompetensi Guru (UKG). Secara nasional rata-rata nilai UKG baru mencapai 53,02. Angka tersebut di bawah 
standar kompetensi minimal yang ditetapkan yakni 55,0. Hanya tujuh provinsi yang mencapai di atas standar nilai UKG yakni Bali, Kep. Bangka Belitung, DKI Jakarta, Jawa Barat, Jawa Timur, dan DI Yogyakarta (Taufik, 2018: 1). Sementara 27 provinsi lainnya masih belum mencapai batas minimal. Kedua, rendahnya kemampuan guru dalam mengajar yang berdampak pada rendahnya pencapaian prestasi hasil belajar siswa baik pada tingkat lokal maupun global. Ketiga, variabilitas kemampuan guru di lapangan sangat tinggi. Minimnya pengalaman mengajar, lemahnya penguasaan teknologi informasi, dan rendahnya motivasi untuk terus mengambangkan pengetahuan dan keterampilan mengajar memberikan kontribusi yang besar terhadap kualitas pengajaran. Jika melihat kondisi saat ini, di kota-kota besar memang telah banyak guru yang memiliki kesadaran tinggi untuk selalu mengembangkan diri baik dari sisi keilmuan maupun keterampilan mengajar. Namun, di banyak daerah masih banyak juga guru yang mengalami hambatan dalam pengembangan diri yang disebabkan berbagai hal baik karena keterbatasan sarana dan prasarana maupun faktor dari pribadi guru itu sendiri.

Rendahnya kualitas guru salah satunya disebabkan oleh sistem rekrutmen yang longgar. Hal tersebut berakibat pada adanya guru yang belum memenuhi kualifikasi yang dipersyaratkan bahkan jauh setelah ditetapkannya UUGD. Kondisi ini terjadi karena tingginya kebutuhan guru di lapangan terutama di daerah khusus. Kekurangan guru yang mendesak mengakibatkan sebagian masyarakat berpandangan bahwa asalkan memiliki pengetahuan dan memiliki minat atau keinginan mengajar siapapun dapat menjadi guru meskipun tidak disertai bakat, keterampilan, dan kualifikasi akademik yang sesuai untuk dapat mendidik siswa.

\section{Guru Sebagai Tenaga Profesional}

Secara konseptual, istilah profesi menunjuk pada suatu pekerjaan atau jabatan yang menuntut keahlian, tanggung jawab, dan kesetiaan terhadap pekerjaan tersebut (Mahpudz, 2014: 2). Sementara menurut Hosnan (2016: 111) profesi adalah suatu kepandaian khusus yang dimiliki oleh seseorang yang diperoleh melalui pendidikan. Sebagai sebuah profesi, guru telah mendapat pengakuan dari negara dan masyarakat. Sebagai bidang pekerjaan khusus, profesi guru menuntut adanya spesifikasi keahlian yang tidak dimiliki oleh semua orang. Salah satu bentuk pengakuan negara terhadap guru adalah ditetapkannya tanggal 25 November sebagai Hari Guru Nasional berdasarkan Keppres. No. 78 tahun 1994. Disamping itu, hak, kewajiban, serta penghargaan terhadap guru juga telah dituangkan dalam berbagai peraturan. Masyarakat menganggap bahwa profesi guru adalah pekerjaan yang mulia, sehingga layak jika guru disebut sebagai pahlawan tanpa tanda jasa.

Dalam upaya pembangunan pendidikan nasional, sangat diperlukan guru (pendidik) dalam standar mutu kompetensi dan profesionalisme yang terjamin (Disas, 2017: 158). Guru yang kompeten dan profesional akan memberikan kontribusi yang besar dalam peningkatan kualitas kegiatan belajar mengajar dan meningkatkan mutu pendidikan. Oleh karena itu guru dituntut untuk senantiasa meningkatkan kompetensinya. Sebab guru yang kompeten merupakan kunci pendidikan yang efektif (Andina, 2018: 205). Guru juga harus bersikap profesional agar tujuan pendidikan nasional dapat tercapai secara optimal.

UUGD memberikan stimulus dan motivasi kepada guru untuk meningkatkan kualifikasi akademik, kompetensi, serta kemampuan dan hal lain yang dipersyaratkan dalam rangka menjadi Guru Profesional (Sholikah, 2017: 6). UUGD Pasal 1 menyatakan bahwa guru adalah pendidik profesional dengan tugas utama mendidik, mengajar, membimbing, mengarahkan, melatih, menilai, dan mengevaluasi peserta didik pada pendidikan anak usia dini jalur pendidikan formal, pendidikan dasar, dan pendidikan menengah. Makna profesional lebih lanjut dijelaskan sebagai individu yang mampu melaksanakan pekerjaan atau kegiatan yang menjadi sumber penghasilan kehidupan, memerlukan keahlian, kemahiran, atau kecakapan dan memenuhi standar mutu atau norma tertentu serta memerlukan bekal 
pendidikan profesi (Martianingsih, 2015: 252). Dengan demikian untuk dapat berprofesi sebagai seorang guru harus memenuhi pendidikan profesi dan memiliki keahlian atau kompetensi yang dibutuhkan. Sebagai bukti bahwa seorang guru memiliki kompetensi adalah dengan adanya sertifikat pendidik. Guru yang telah memiliki sertifikat pendidik dapat dinyatakan sebagai guru profesional.

Sertifikat pendidik diperoleh melalui program sertifikasi guru. Kebijakan program sertifikasi guru sudah diterapkan sejak tahun 2007/2008. Adapun pelaksanaan sertifikasi guru dalam jabatan diatur dalam Peraturan Menteri Pendidikan Nasional (Permendiknas) No. 18 Tahun 2007 tentang Sertifikasi bagi Guru Dalam Jabatan. UUGD pasal 11 menyebutkan bahwa Pelaksanaan sertifikasi dilaksanakan dengan ketentuan: Pertama, sertifikat pendidik diberikan kepada guru yang telah memenuhi persyaratan; Kedua, sertifikasi pendidik diselenggarakan oleh perguruan tinggi yang memiliki program pengadaan tenaga kependidikan yang terakreditasi dan ditetapkan oleh Pemerintah; dan Ketiga, sertifikasi pendidik dilaksanakan secara objektif, transparan, dan akuntabel.

Program sertifikasi guru dari tahun ke tahun terus mengalami penyempurnaan. Penyempurnaan tersebut antara lain mencakup perubahan kebijakan, prosedur, mekanisme penetapan peserta, lembaga pelaksana, serta pola sertifikasi yang digunakan. Program sertifikasi guru dimulai pada tahun 2007, di mana pada persyaratan untuk mengikuti sertifikasi adalah guru yang telah memenuhi ketentuan dan terdaftar dalam program sertifikasi tersebut pada tahun 2006. Guru yang berhak mengikuti program sertifikasi adalah guru yang memiliki kualifikasi akademikminimalS-1 atauD-IV.Proses sertifikasi dilakukan dengan uji kompetensi melalui penilaian portofolio. Kelengkapan dokumen portofolio yang dinilai mencakup dokumen tentang kualifikasi akademik, pendidikan dan pelatihan, pengalaman mengajar, perencanaan dan pelaksanaan pembelajaran, penilaian dari atasan dan pengawas, prestasi akademik, karya pengembangan profesi, keikutsertaan dalam forum ilmiah, pengalaman organisasi di bidang pendidikan dan sosial, serta penghargaan yang relevan dengan bidang pendidikan.

Peserta yang dinyatakan lulus program sertifikasi berhak menerima sertifikat pendidik dan tunjangan profesi sebagaimana diatur dalam Permendiknas No 36 Tahun 2007. Sementara peserta yang tidak lulus diwajibkan melengkapi dokumen portofolio untuk diajukan pada tahun berikutnya atau mengikuti Program Pendidikan dan Latihan Profesi Guru (PLPG). PLPG merupakan program sertifikasi guru dalam jabatan yang dilaksanakan melalui jalur pendidikan sebagaimana diatur dalam Permendiknas No. 40 Tahun 2007. PLPG dilaksanakan selama dua semester dan diakhiri dengan serangkaian ujian akhir yang meliputi ujian tertulis, ujian praktek mengajar, dan uji kompetensi sosial dan kepribadian. PLPG dilaksanakan oleh LPTK yang ditunjuk oleh pemerintah dan telah memenuhi persyaratan.

Dalam rangka percepatan proses sertifikasi untuk memenuhi target seluruh guru telah bersertifikat pada tahun 2015 sebagaimana amanat UUGD dan SNP, pemerintah merevisi ketentuan kualifikasi persyaratan pendidikan bagi peserta sertifikasi melalui PP No. 74 Tahun 2008 tentang Guru dan Permendiknas No. 10 Tahun 2009. Dalam peraturan tersebut disebutkan bahwa guru-guru yang belum memenuhi kualifikasi akademik S-1 atau D-IV dapat mengikuti program sertifikasi guru dalam jabatan melalui jalur penilaian portofolio dengan syarat telah berusia 50 tahun dan memiliki pengalaman kerja 20 tahun atau yang mempunyai golongan IVa, atau yang memiliki angka kredit setara dengan golongan IVa.

Pemerintah menghentikan program PLPG di tahun 2017, dengan pertimbangan bahwa sudah tidak sesuai lagi dengan UUGD. Sebagai tindak lanjut pemerintah mengeluarkan kebijakan PPG dalam jabatan yang dengan ketentuan yang diatur dalam PP No. 19 Tahun 2017 yang di dalamnya mengatur tentang rintisan PPG dalam jabatan bagi guru produktif SMK. Adapun ketentuan penyelenggaraannya diatur dalam Permenristekdikti No. 55 Tahun 2017. 
Kebijakan program sertifikasi dalam jabatan yang berlangsung sejak tahun 2007 sampai dengan saat ini merupakan program pemerintah jangka pendek dan jangka menengah yang sekaligus merupakan program peralihan menuju sistem sertifikasi jangka panjang yakni program sertifikasi prajabatan. Penyelenggaraan program sertifikasi prajabatan ini terintegrasi dalam program PPG Prajabatan. PPG Prajabatan diselenggarakan dengan landasan Permendiknas No. 8 Tahun 2009 tentang Program Pendidikan Profesi Guru Prajabatan. Implikasi dari adanya sertifikasi prajabatan ini adalah adanya keharusan dalam sistem seleksi guru yang lebih baik. Berdasarkan kebijakan tersebut calon-calon guru yang layak dan memenuhi syarat untuk diangkat sebagai guru adalah calon-calon guru yang memiliki kualifikasi pendidikan yang tepat, berkompeten dan telah memiliki sertifikat profesi guru. hal tersebut sesuai dengan ketentuan dalam UU Sisdiknas yang menyatakan bahwa seseorang memiliki kewenangan mengajar jika ia telah memiliki sertifikat profesi guru.

\section{Standar Kompetensi Guru Profesional}

Dalam rangka mendukung pembangunan bangsa melalui pendidikan, guru mengambil peran yang sangat vital. Guru berperan penting dalam hal penjaminan dan peningkatan mutu pendidikan melalui kegiatan belajar mengajar dan pegembangan keilmuan. Dengan dihapusnya standar nilai UN dari syarat kelulusan siswa pada jenjang dasar dan menengah maka kualitas pendidikan saat ini ditentukan oleh kualitas guru sebagai pelaksana pendidikan. Salah satu faktor yang mengakibatkan turunnya nilai $\mathrm{UN}$ adalah masih rendahnya kualitas guru dalam mengajar. Hal tersebut dipicu oleh terbatasnya penguasaan guru terhadap materi yang akan diajarkan serta terbatasnya keterampilan mengajar.

Untuk dapat melaksanakan pembelajaran secara efektif terdapat 4 (empat) kompetensi yang harus dimiliki oleh guru, yaitu: kompetensi pedagogik, kompetensi kepribadian, kompetensi sosial dan kompetensi profesional (Direktorat Ketenagaan, Direktorat Jenderal Pendidikan Tinggi, Departemen Pendidikan Nasional, 2008a).
Kompetensi tersebut merupakan kompetensi dasar yang menentukan keberhasilan kegiatan belajar mengajar. Secara lebih rinci, hal-hal yang perlu dikuasai guru pada masing-masing kompetensi tersebut adalah sebagai berikut.

Pertama, Kompetensi Pedagogik. Kompetensi pedagogik berkaitan dengan kemampuan pengelolaan pembelajaran. Kompetensi pedagogik meliputi penguasaan teori belajar dan pembelajaran (Andriani, Sumarmi, \& Astina, 2016: 2106). Sebagai fasilitator dalam mengaktualisasikan dan memaksimalkan pengembangan berbagai potensi yang dimiliki peserta didik, seorang guru selayaknya mampu memahami karakteristik peserta didik dari aspek fisik, moral, sosial, kultural, emosional, dan intelektual. Hal tersebut ditunjang dengan penguasaan yang matang terhadap teoriteori belajar dan pengembangan kurikulum yang terkait dengan bidang ajar yang diampu serta keterampilan dalam memanfaatkan teknologi informasi dan komunikasi guna kepentingan penyelenggaraan kegiatan pengembangan kompetensi dalam hal pendidikan dan pengajaran. Guru juga harus terampil mengelola aktivitas belajar di kelas, mengoptimalkan berbagai fasilitas dan lingkungan sebagai sumber dan media belajar, berkomunikasi secara efektif, empatik, dan santun dengan peserta didik dengan tetap memperhatikan etika profesi guru, melakukan penilaian dan evaluasi untuk mengetahui capaian pembelajaran, serta melakukan tindakan reflektif guna peningkatan kualitas kegiatan pembelajaran.

Kedua, Kompetensi Kepribadian. Setiap guru memiliki ciri-ciri kepribadian yang membedakan kepribadian guru yang satu dengan guru yang lainnya. Setiap perkataan, tindakan, perbuatan dan tingkah laku yang positif akan meningkatkan citra diri dan kepribadian seseorang (Anwar, 2011: 146). UUGD Pasal 10 Ayat 1 memberikan penjelasan bahwa kompetensi kepribadian kemampuan kepribadian yang mantap, berakhlak mulia, arif, dan berwibawa serta menjadi teladan peserta didik. Kemampuan kepribadian tersebut tampak dalam setiap aktivitas keseharian baik di dalam maupun di luar kelas. Kompetensi kepribadian guru memiliki pengaruh terhadap kebiasaan-kebiasaan belajar siswa termasuk 
motivasi belajar siswa (Huda, 2017: 242). Pada dasarnya kepribadian merupakan hal yang abstrak, sehingga hanya indikatornya yang dapat diketahui. Berkaitan dengan hal tersebut seorang guru harus bertindak sesuai dengan norma-norma yang berlaku baik norma agama, hukum, kesopanan, susila, serta menjunjung tinggi budaya nasional Indonesia. Guru juga harus berakhlak mulia sehingga dapat menjadi teladan teladan bagi peserta didik, sesama guru dan masyarakat luas; tampil sebagai pribadi yang mantap, stabil, dewasa, arif, bijaksana, dan berwibawa; menunjukkan etos kerja, disiplin, tanggung jawab, rasa bangga, dan rasa percaya diri yang tinggi sebagai seorang guru; serta menjunjung tinggi etika profesi guru.

Ketiga, Kompetensi Sosial. Dalam kaitannya dengan interaksi guru baik di kelas maupun diluar kelas diperlukan kompetensi sosial. UUGD Pasal 10 Ayat 1 memberikan penjelasan bahwa kompetensi sosial guru adalah kemampuan untuk berkomunikasi dan berinteraksi secara efektif dan efisien dengan siswa, guru, orang tua/ wali peserta didik, dan masyarakat. Kompetensi sosial guru diwujudkan dalam keseharian dengan bersikap inklusif, bertindak objektif, serta tidak diskriminatif baik terhadap jenis kelamin, agama, ras, kondisi fisik, latar belakang keluarga, maupun status sosial ekonomi tertentu. Dalam aktivitas sehari-hari guru melakukan komunikasi secara efektif, empatik, dan santun dengan sesama pendidik, tenaga kependidikan, orang tua, dan masyarakat. Guru juga diharapkan dapat dengan mudah beradaptasi dalam menjalankan tugas pada penempatan di seluruh wilayah Republik Indonesia yang memiliki ragam sosial budaya serta aktif menjalin komunikasi dengan komunitas profesi guru dan komunitas profesi lain baik secara lisan, tulisan, maupun bentuk komunikasi lainnya. Kompetensi sosial guru dianggap sebagai salah satu daya atau kemampuan guru untuk mempersiapkan siswa menjadi anggota masyarakat yang baik serta kemampuan untuk mendidik dan membimbing masyarakat dalam masa yang akan datang (Lutfiyah \& Winaryati, 2017: 208). Berkaitan dengan hal tersebut aktivitas mengajar di kelas merupakan perwujudan kemampuan sosial guru melalui interaksi dalam proses komunikasi.

Keempat, Kompetensi Profesional. Kompetensi profesional guru dapat diartikan sebagai penguasaan terhadap pengetahuan, keterampilan, nilai dan sikap yang direfleksikan dalam kebiasaan berpikir dan bertindak dalam menjalankan profesi sebagai guru (Nuraidah, 2013: 8). Dengan demikian kompetensi profesional guru adalah sejumlah kompetensi yang berhubungan dengan profesi yang menuntut berbagai keahlian di bidang pendidikan atau keguruan (Dudung, 2018: 16). Dalam penjelasan UUGD Pasal 10 Ayat 1, seorang guru dikatakan memiliki kompetensi profesional jika guru tersebut kemampuan penguasaan materi pelajaran secara luas dan mendalam. Dalam hal ini penguasaan materi tersebut mencakup struktur, konsep, dan pola pikir keilmuan berkaitan dengan bidang studi yang diampu. Hal tersebut ditunjukkan dengan penguasaan standar kompetensi, kompetensi inti, dan kompetensi dasar secara menyeluruh pada bidang studi yang diampu. Guru dituntut untuk selalu berinovasi dan meningkatkan kreativitas guna pengembangan materi pembelajaran. Guru juga diharapkan meningkatkan profesionalitasnya secara kontinu dengan melakukan berbagai tindakan reflektif, serta senantiasa berkomunikasi dan melakukan kegiatan pengembangan diri dengan memanfaatkan kemajuan teknologi informasi dan komunikasi.

Peranan guru dalam proses pembelajaran tidak akan terlepas dari aktivitas mengajar, mendidik, dan membimbing. Sebagai pengajar, guru lebih terkonsentrasi kepada tugas menyiapkan dan melaksanakan proses pembelajaran. Sementara sebagai pembimbing guru lebih menekankan pada bimbingan dalam memecahkan problem yang dihadapi siswa, adapun sebagai administrator kelas, guru memiliki keterkaitan dengan sistem administrasi di kelas disamping melaksanakan tugas pengajaran dan bimbingan (Musfah, 
2015: 181). Berkaitan dengan banyaknya aktivitas guru dalam kesehariannya di dalam kegiatan kelas maka standar kompetensi guru menjadi keharusan bagi setiap guru.

\section{Guru Profesional dan Penyelenggaraan PPG Prajabatan}

Profesionalisme adalah sebutan yang mengacu pada sikap mental dalam bentuk komitmen dari para anggota suatu profesi untuk senantiasa mewujudkan dan meningkatkan kualitas profesionalnya (Hosnan, 2016: 95). Seorang guru yang memiliki profesionalisme yang tinggi akan melakukan pelbagai cara dan strategi sebagai bentuk perwujudan dan pengembangan profesionalisme guru yang tercermin dalam sikap mental dan komitmen yang kuat. UUGD Pasal 1 Ayat 4 menjelaskan bahwa profesional adalah pekerjaan atau kegiatan yang dilakukan seseorang dan menjadi sumber penghasilan kehidupan yang memerlukan keahlian, kemahiran, atau kecakapan yang memenuhi standar mutu serta memerlukan pendidikan profesi.

Guru sebagai sebuah profesi, berlaku bagi mereka yang telah tersertifikasi. Mereka yang belum tersertifikasi disebut sarjana mengajar. Untuk menjadi guru profesional mereka wajib mengikuti PPG sebagai pendidikan profesi. Aturan tersebut dianggap kontroversial karena pasca berlakunya UUGD, profesi guru menjadi profesi yang terbuka. Profesi guru dapat diisi oleh setiap orang yang memiliki latar belakang pendidikan akademik S-1/D-IV baik yang berasal dari lulusan sarjana pendidikan (S.Pd) maupun sarjana nonkependidikan. Hal ini sejalan dengan penghapusan Akta Mengajar atau Akta IV pada lulusan sarjana pendidikan.

Dalam Permendikbud No 87 Tahun 2013 tentang Program Pendidikan Profesi Guru (PPG) Prajabatan, pada pasal 1, dijelaskan bahwa PPG Prajabatan adalah program pendidikan yang diselenggarakan untuk mempersiapkan lulusan S-1 Kependidikan dan S-1/D-IV Non kependidikan yang memiliki bakat dan minat menjadi guru agar menguasai kompetensi guru secara utuh sesuai dengan Standar Nasional Pendidikan. Dengan begitu, mereka dapat memperoleh sertifikat pendidik profesional dan siap mengajar pada jenjang pendidikan anak usia dini, pendidikan dasar, maupun pendidikan menengah sesuai dengan bidang pendidikan profesi yang telah ditempuh.

Sejalan dengan UU No. 20 Tahun 2003 Pasal 3 Tujuan umum PPG Prajabatan adalah menghasilkan calon guru yang memiliki kemampuan mewujudkan tujuan pendidikan nasional, yaitu mengembangkan potensi peserta didik agar menjadi manusia yang beriman dan bertakwa kepada Tuhan Yang Maha Esa, berakhlak mulia, sehat, berilmu, cakap, kreatif, mandiri, dan menjadi warga negara yang demokratis serta bertanggung jawab (Ningrum, 2012: 50). Sementara tujuan khususnya sebagaimana tercantum dalam Permendikbud No. 87 Tahun 2013 adalah menghasilkan calon guru yang memiliki kompetensi dalam merencanakan, melaksanakan, dan menilai pembelajaran; menindaklanjuti hasil penilaian; melakukan pembimbingan dan pelatihan pada peserta didik; serta berkontribusi dalam pengembangan ilmu pengetahuan melalui kegiatan penelitian. Tujuan ini juga sejalan dengan tujuan dari program studi kependidikan S-1 di semua kampus IKIP dan eks IKIP (Subkhan, 2016: 316).

PPG Prajabatan memberikan bekal kepada calon guru serta mengembangkan kompetensi profesional calon guru melalui kegiatan lokakarya dan praktik mengajar dalam keadaan sesungguhnya. Praktik mengajar dilaksanakan secara terpadu pada praktik pengalaman lapangan (PPLK) kependidikan. Dalam kegiatan tersebut calon guru dapat mengaplikasikan kompetensi akademik yang telah dicapai pada pendidikan S-1 sekaligus memperoleh penguatan. Sasaran utama Program PPG Prajabatan adalah mewujudkan guru-guru yang profesional, yakni guru-guru yang berkompeten baik secara keilmuan maupun keterampilan mengajar.

ProgramPPG diselenggarakan oleh perguruan tinggi yang memiliki lembaga pendidikan tenaga kependidikan yang memenuhi persyaratan dan ditetapkan oleh Menteri (Permendikbud No. 87 Tahun 2013 Pasal 3 ayat 1). Di mana dalam UUGD Ayat 14 dijelaskan bahwa Lembaga 


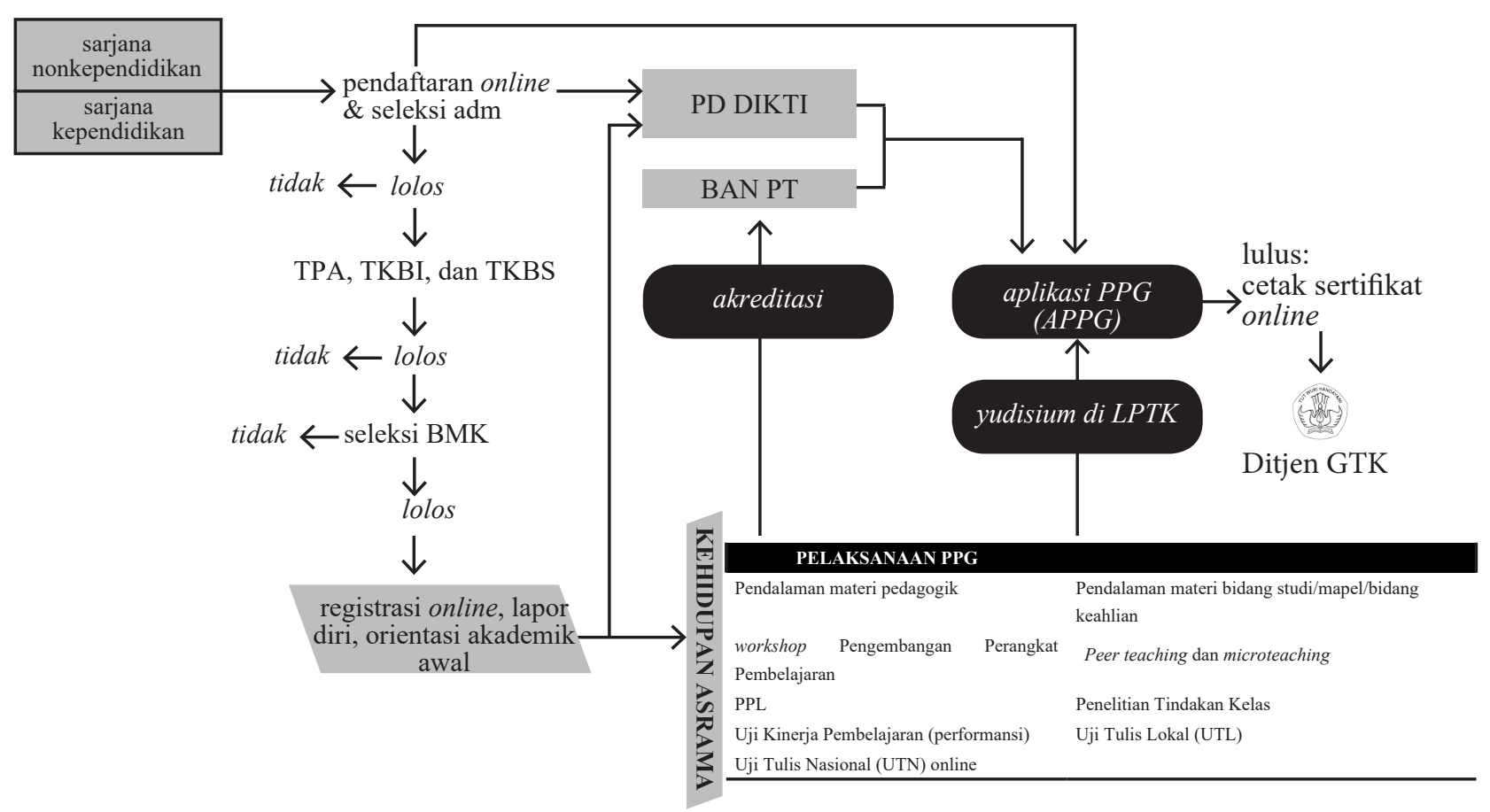

Gambar 1. Alur Seleksi dan pelaksanaan PPG Prajabatan Bersubsidi Sumber: Dirjen Belmawa Kemenristekdikti 2019.

Pendidikan Tenaga Kependidikan (LPTK) adalah perguruan tinggi yang diberi tugas oleh Pemerintah untuk menyelenggarakan program pengadaan guru pada pendidikan anak usia dini jalur pendidikan formal, pendidikan dasar, dan/atau pendidikan menengah, serta untuk menyelenggarakan dan mengembangkan ilmu kependidikan dan nonkependidikan.

Persyaratan yang harus dipenuhi oleh LPTK untuk dapat menyelenggarakan PPG diatur dalam Permenristekdikti No. 55 Tahun 2017. Dalam peraturan tersebut pasal 28 menyebutkan bahwa LPTK penyelenggara Program PPG terakreditasi oleh Badan Akreditasi Nasional Perguruan Tinggi (BAN-PT) atau Lembaga Akreditasi Mandiri (LAM). Disamping itu LPTK memiliki Program Sarjana Pendidikan dalam bidang studi sejenis dengan Program PPG yang akan diselenggarakan. LPTK penyelenggara Program PPG produktif kejuruan melibatkan perguruan tinggi penyelenggara pendidikan vokasi, industri, dan praktisi yang relevan dalam proses pembelajaran, sementara Program PPG yang berkaitan dengan karakteristik bidang keahlian kejuruan, seni, olahraga, dan keahlian khusus lainnya ditetapkan oleh Direktur Jenderal sebagaimana dijelaskan dalam pasal 30. Pelibatan dunia industri dan praktisi merupakan keharusan, sebab calon guru membutuhkan wawasan yang luas di mana dunia usaha/dunia industri selalu berkembang mengikuti kebutuhan pasar.

Peserta PPG Prajabatan lulusan S-1 Kependidikan dan S-1/D-IV Non kependidikan yang memiliki bakat dan minat menjadi guru. Kriteria seleksi PPG Prajabatan meliputi kemampuan pedagogik, profesional, sosial, kepribadian, bakat, serta minat untuk menjadi guru. Untuk dapat mengikuti PPG Prajabatan peserta harus mengikuti tahapan seleksi yang telah ditentukan.

Gambar 1 menunjukkan mengenai mekanisme seleksi dan pelaksanaan PPG Prajabatan. Proses seleksi diawali dengan melakukan pendaftaran online dan seleksi administrasi. Selanjutnya peserta yang lolos seleksi administrasi wajib mengikuti tes tertulis mencakup Tes Potensi Akademik (TPA), Tes Kemampuan bahasa Inggris (TKBI), serta Tes Kemampuan Bidang Studi (TKBS) dan Pedagogik. Peserta yang lolos, selanjutnya wajib mengikuti Seleksi Bakat, Minat, dan Kepribadian 
(BMK). Setelah dinyatakan lolos pada seluruh rangkaian seleksi, selanjutnya peserta melakukan registrasi online, lapor diri, dan mengikuti orientasi akademik awal.

Struktur kurikulum program PPG Prajabatan berisi lokakarya pengembangan perangkat pembelajaran, latihan mengajar melalui pembelajaran mikro, pembelajaran pada teman sejawat, dan Program Pengalaman Lapangan (PPL), dan program pengayaan bidang studi (subject enrichment) dan/atau pedagogi. Namun sebelum mengikuti perkuliahan PPG calon peserta PPG harus terlebih dahulu mengikuti dan lulus program matrikulasi. Program matrikulasi adalah sejumlah mata kuliah yang wajib diikuti oleh peserta program PPG yang sudah dinyatakan lulus seleksi untuk memenuhi kompetensi akademik bidang studi dan/atau kompetensi akademik kependidikan sebelum mengikuti program PPG (Permendikbud No. 87 Tahun 2013 Pasal 1 Ayat 4).

Sistem pembelajaran pada program PPG mencakup lokakarya pengembangan perangkat pembelajaran dan PPL yang yang berorientasi pada pencapaian kompetensi merencanakan dan melaksanakan proses pembelajaran, menilai hasil pembelajaran, menindaklanjuti hasil penilaian, serta melakukan pembimbingan dan pelatihan. Adapun penyelenggaraannya dilaksanakan dengan pemantauan langsung secara intensif oleh dosen pembimbing dan guru pamong yang ditugaskan khusus untuk kegiatan tersebut. Beban belajar program PPG Prajabatan ditetapkan berdasarkan latar belakang pendidikan/keilmuan peserta didik program PPG Prajabatan dan satuan pendidikan tempat penugasan.

Bagi lulusan S-1/D-IV kependidikan, muatan pendidikannya dititikberatkan pada penguatan kompetensi profesional, terdiri dari kajian akademik keahlian pendidikan bidang studi (subject specific pedagogy), yang merupakan keahlian pendidikan bidang studi yang didalamnya mencakup standar kompetensi, materi, model, strategi, metoda, media, serta evaluasi; dan PPL Kependidikan. Sementara bagi lulusan S-1/D-IV nonkependidikan muatan pendidikannya dititikberatkan pada pengembangan kompetensi pedagogik yang terdiri dari kajian akademik kependidikan (pedagogical content) yang memuat tentang teori pendidikan, pembelajaran, dan peserta didik; kompetensi kepribadian pendidik; serta kajian akademik keahlian pendidikan bidang studi (subject specific pedagogy) seperti pengemasan materi bidang studi untuk pembelajaran bidang studi yang mendidik; dan PPL Kependidikan.

Setelah selesai menempuh pendidikan selama satu tahun dan lulus uji kompetensi guru (UKG), peserta PPG Prajabatan baik yang berasal dari sarjana pendidikan maupun sarjana nonkependidikan berhak mendapatkan sertifikat pendidik dan menyandang gelar $\mathrm{Gr}$ (guru). Dengan ini secara formal administratif dapat disebut calon guru profesional dibuktikan dengan telah memiliki sertifikat profesi. Dengan demikian mereka siap bersaing menjadi untuk menduduki jabatan guru profesional pada institusi pendidikan sesuai dengan jenjang yang ditekuni yakni pendidikan dasar, menengah, maupun pendidikan usia dini.

\section{Permasalahan dalam Penyelenggaraan PPG Prajabatan}

Salah satu permasalahan yang dihadapi dalam penyelenggaraan PPG berkaitan dengan LPTK sebagai penyelenggara program. Pertama, terkait pemerataan kualitas LPTK. Belum semua LPTK memenuhi Permenristekdikti No. 55 Tahun 2017 tentang Standar Pendidikan Guru dan keterbatasan anggaran. Dalam peraturan tersebut LPTK penyelenggara PPG harus memenuhi ketentuan: a) memiliki program studi kependidikan strata satu (S-1) yang: (1) sama dengan program PPG yang akan diselenggarakan; (2) terakreditasi oleh Badan Akreditasi Nasional Perguruan Tinggi (BAN-PT) dengan peringkat paling rendah B; (3) memiliki dosen tetap paling sedikit 2 (dua) orang berkualifikasi doktor (S-3) dengan jabatan akademik paling rendah Lektor, dan 4 (empat) orang berkualifikasi Magister (S-2) dengan jabatan akademik paling rendah Lektor Kepala berlatar belakang pendidikan sama dan/atau sesuai dengan program PPG yang akan diselenggarakan, paling sedikit salah 
satu latar belakang strata pendidikan setiap dosen tersebut adalah bidang kependidikan. b) memiliki sarana dan prasarana yang mendukung penyelenggaraan program PPG, termasuk asrama mahasiswa sebagai bagian integral dalam proses penyiapan guru profesional; c) memiliki rasio antara dosen dengan mahasiswa pada masingmasing program studi sesuai SPMI; d) memiliki program peningkatan dan pengembangan aktivitas instruksional atau yang sejenis dan berfungsi efektif; e) memiliki program dan jaringan kemitraan dengan sekolah-sekolah mitra terakreditasi paling rendah $\mathrm{B}$ dan memenuhi persyaratan untuk pelaksanaan program pengalaman lapangan (PPL); f) memiliki laporan evaluasi diri dan penjaminan mutu berdasar fakta, paling sedikit 2 (dua) tahun terakhir.

Berdasarkan hasil akreditasi Badan Akreditasi Nasional Perguruan Tinggi (BAN PT), pada tahun 2019 dari 433 LPTK yang tersebar di seluruh Indonesia, baru 36 (8,31\%) terakreditasi A, 179 (41,34\%) terakreditasi B, dan $218(50,35 \%)$ terakreditasi $\mathrm{C}$ dan belum terakreditasi (Dirjen Belmawa Kemenristekdikti, 2019). Keberadaan LPTK ini juga tidak merata di seluruh Indonesia. Dari 51 LPTK yang ditunjuk dan memenuhi persyaratan sebagai penyelenggara PPG, 47 LPTK (71\%) diantaranya berada di Indonesia barat, sementara Indonesia timur hanya terdapat 4 LPTK. Hal ini menunjukkan bahwa kesenjangan pemerataan kualitas LPTK sangat tinggi. Kesenjangan ini tentu menimbulkan perbedaan akses yang sangat besar sehingga persaingan untuk masuk sebagai peserta PPG di wilayah Indonesia bagian tengah dan bagian timur menjadi semakin ketat.

Permasalahan ini juga menimbulkan permasalahan turunan yang lain. Salah satunya pada terjadinya peristiwa penolakan di beberapa daerah terhadap penempatan guru profesional di daerahnya. Pada tahun 2017 terjadi penolakan terhadap penempatan Guru Garis Depan (GGD) salah satunya di Kabupaten Sintang, Kalimantan Barat yang dilatarbelakangi oleh kecemburuan. Pada dasarnya tidak ada yang salah baik pada proses rekrutmen maupun kualifikasi guru pada program tersebut. Guru yang direkrut merupakan alumni Program Sarjana Mendidik di daerah Terluar, Terdepan dan Tertinggal (SM3T) yang telah selesai menempuh PPG dan direkrut melalui mekanisme yang profesional. Namun demikian, terdapat kendala pada proses penempatan dikarenakan adanya kecemburuan dari pihak daerah penempatan yang menilai bahwa pemerintah diskriminatif dan mengesampingkan peran putra daerah yang telah lama mengabdi pada institusi pendidikan, sementara di daerah tersebut tidak ada LPTK yang memenuhi kelayakan dan ditunjuk sebagai penyelenggara PPG.

Kedua, dari sisi sarana dan prasarana. Masih banyak LPTK yang belum memiliki sarana dan prasarana yang memadai. Masih banyak bangunan gedung dan ruang belajar belum sesuai standar. Serta belum semua LPTK memiliki asrama untuk mahasiswa PPG. Alih-alih memenuhi sarana dan prasarana termutakhir, saat ini pemerintah masih dibebani pekerjaan rumah, baik untuk meneruskan pembangunan gedung berstatus konstruksi dalam pengerjaan (KDP), maupun memenuhi kekurangan kebutuhan infrastruktur di berbagai perguruan tinggi (Sudjatmiko, 2019).

Ketiga, terkait modul belajar dan variabilitas dosen pengajar. Masih terdapat masalah pula terbatasnya modul belajar dan variabilitas kemampuan inovasi dosen pengajar PPG. Modul belajar merupakan salah satu bahan ajar dalam baik dalam bentuk softfile maupun hardfile (cetak) yang digunakan sebagai alat untuk belajar secara mandiri dan digunakan seorang pengajar untuk memberikan materi kepada secara runtut. Namun demikian dalam pelaksanaan perkuliahan belum semua mata kuliah dilengkapi dengan modul belajar. Di sisi lain meskipun telah memiliki kualifikasi pendidikan yang sesuai dengan yang dalam peraturan, kemampuan inovasi dosen pengajar masih berbeda-beda. Masih banyak dosen yang mengajar masih dengan model lama yang kurang inovatif, sementara calon guru profesional tentunya dituntut untuk selalu mengembangkan inovasi dan memanfaatkan segala sumber belajar dengan optimal dalam kegiatan belajar mengajar.

Keempat, terkait laboratorium dan sistem kemitraan dengan sekolah mitra/dunia industri. 
Permasalahan lain yang juga harus segera diselesaikan adalah belum semua LPTK memiliki laboratorium dan sistem kemitraan dengan sekolah mitra/dunia industri yang terstandar, serta tidak semua jenis guru dapat dihasilkan oleh LPTK (Dirjen Belmawa Kemenristekdikti, 2019). Idealnya LPTK sebagai pencetak calon guru profesional dilengkapi dengan laboratorium sekolah yang standar serta memiliki mitra/dunia industri sebagai penguatan kompetensi. Hal ini untuk lebih memantapkan dan mengoptimalkan kegiatan praktikum yang diselenggarakan. Di sisi lain tidak semua jenis guru dapat dihasilkan oleh LPTK misalnya guru produktif di SMK, banyak guru produktif di SMK yang yang berasal dari lulusan nonkependidikan.

Kelima, terkait program studi PPG. Pemenuhan calon guru profesional juga masih terkendala pada belum tersedianya program studi pada mata pelajaran tertentu. Misalnya pada mata pelajaran IPA pada jenjang SMP. Hal tersebut tentu menjadi permasalahan sebab pemenuhan guru profesional pada mata pelajaran tersebut belum dapat dipenuhi melalui PPG Prajabatan. Dengan demikian maka perlu adanya penambahan program studi dalam PPG agar setiap mata pelajaran dapat disiapkan guru profesional untuk sebagai pengampu.

Permasalahan lain yang terjadi dalam penyelenggaraan PPG Prajabatan terkait seleksi calon peserta didik dan optimalisasi daya serap lulusan. Terbukanya peluang bagi lulusan Non Pendidikan untuk dapat mengikuti PPG Prajabatan merupakan tantangan tersendiri bagi Lembaga Pendidikan Tinggi Keguruan (LPTK) dan bagi lulusan ilmu kependidikan atau sarjana pendidikan, sebab banyaknya lulusan sarjana pendidikan tidak berbanding lurus dengan kuota penerimaan peserta didik dalam PPG Prajabatan. Sementara bagi lulusan nonkependidikan PPG Prajabatan membuka peluang bagi mereka untuk dapat menjadi guru selain dapat juga berkecimpung di bidang yang sesuai ilmu yang ditekuni pada jenjang pendidikan S-1. Kondisi ini seakan berusaha mematikan LPTK, sebab baik sarjana pendidikan maupun sarjana nonkependidikan memiliki peluang yang sama untuk menjadi guru profesional.

Diperbolehkannya lulusan nonkependidikan untuk mengikuti program PPG dirasa telah merebut lahan kerja bagi lulusan kependidikan. Termasuk dengan diperbolehkannya lulusan S-1 Ilmu Psikologi untuk mengikuti PPG Prajabatan sebagai calon guru Pendidikan Anak Usia Dini (PAUD) dan Sekolah Dasar (SD) (Subkhan, 2016: 317). Terutama melihat kondisi saat ini terjadi over supply lulusan akademik/ Sarjana Pendidikan (S.Pd.) sementara penyelenggaraan PPG berdasarkan supply and demand. Jika memang seorang calon mahasiswa berminat untuk menjadi guru, atau berjiwa guru maka semestinya sejak awal ia mendaftar di LPTK bukan di kampus umum dan menempuh program studi nonkependidikan. Ujian masuk calon mahasiswa LPTK pada program studi kependidikan seharusnya berbeda dengan ujian masuk calon mahasiswa lain agar dapat menyaring calon-calon guru yang memiliki kompetensi khusus sebagai calon pendidik.

Dari sisi optimalisasi penyerapan lulusan, saat ini pemerintah masih kurang memprioritaskan calon guru profesional lulusan PPG Prajabatan. Hal ini terlihat pada sistem rekrutmen guru yang dilakukan melalui penerimaan CPNS formasi guru tahun 2018. Dalam proses seleksi tersebut pemerintah belum memaksimalkan daya serap calon guru bersertifikasi sebab masih memperbolehkan sarjana pendidikan yang belum mengikuti PPG Prajabatan untuk ikut berkompetisi di dalamnya. Meskipun secara administratif pemegang sertifikat pendidik memiliki prioritas dengan perolehan nilai sempurna pada tahap Tes Kompetensi Bidang (TKB) dengan nilai sempurna tanpa harus mengikuti tes asalkan memenuhi passing grade dan kuota pada Tes Kompetensi Dasar (TKD). Dengan demikian untuk menjadi guru di sebuah institusi pendidikan, lulusan PPG masih harus bersaing dengan mereka yang belum menempuh PPG. Berdasarkan kondisi tersebut calon guru profesional tidak serta merta memiliki peluang yang tinggi untuk dapat menjadi guru meskipun di sisi lain kondisi saat ini kebutuhan guru yang berkualitas sangat tinggi. Pengadaan rekrutmen 
yang berkala dengan kuota yang terbatas masih menjadi permasalahan utama dalam pemenuhan kebutuhan guru yang berkualitas.

Melihat permasalahan tersebut perlu adanya penataan ulang mengenai (1) kualitas LPTK, (2) kualifikasi persyaratan pada seleksi peserta PPG Prajabatan, dan (3) penyerapan lulusan PPG Prajabatan. Dalam rangka penataan ulang kualitas LPTK diperlukan kajian serius dan mendalam tentang jumlah dan jenis LPTK, tata kelola dan penguatan kelembagaan LPTK, kurikulum dan sistem pembelajaran, serta penjaminan mutu khas LPTK. Dengan demikian berkaitan dengan permasalahan pemerataan kualitas LPTK maka upayayang dapatdilakukan adalah(1) peningkatan dukungan fasilitas belajar serta sarana dan prasarana yang memadai, (2) penambahan modul belajar dan peningkatan kualitas dosen pengajar, (3) peningkatan ketersediaan laboratorium dan sistem kemitraan dengan sekolah mitra/dunia industri, (4) penambahan program studi pada PPG demi tersedianya calon guru profesional pada setiap mata pelajaran dan setiap jenjang pendidikan, serta (5) implementasi sistem penjaminan mutu pada LPTK untuk memantau kualitas penyelenggaraan pada setiap standar yang ditetapkan.

Sementara itu, untuk meningkatkan kualifikasi persyaratan seleksi calon peserta didik PPG dapat dilakukan dengan memberikan kebijakan bagi prioritas bagi sarjana pendidikan dengan kuota yang lebih banyak. Disamping itu perlu juga adanya pembatasan bagi sarjana non pendidikan untuk mengikuti program PPG Prajabatan, yakni dengan membatasi hanya pada sarjana non pendidikan yang berasal dari prodi dengan bidang-bidang yang belum mampu dicetak oleh LPTK. Sebagai contoh saat ini LPTK belum mampu mencetak guru-guru produktif di bidang kelautan, pariwisata, dan perikanan. Padahal, saat ini bidang tersebut banyak dibutuhkan di dunia kerja. Dalam rangka optimalisasi penyerapan lulusan PPG Prajabatan dalam hal ini calon guru profesional. Pemerintah hendaknya lebih memberikan prioritas dan peluang yang lebih besar bagi lulusan PPG yang memang disiapkan untuk menjadi guru profesional.

\section{Pemenuhan Kebutuhan Guru Profesional}

Pemenuhan kebutuhan guru baik di pusat maupun di daerah dapat dipenuhi melalui penempatan guru yang memenuhi kualifikasi dan standar kompetensi yang memadai serta sistem seleksi yang profesional pula. Pemetaan kebutuhan guru perlu disusun dengan jelas untuk menghindari ketidakmerataan persebaran guru, sebab saat ini dibeberapa daerah masih mengalami kekurangan guru, sementara di beberapa daerah lainnya terjadi penumpukan guru baik guru mata pelajaran maupun guru kelas.

Berdasarkan hasil Analisis Sumber Daya Manusia Pendidikan Dasar dan Menengah (Dikdasmen) masih terjadi kekurangan guru dikdasmen sebesar 146.987 orang. Kekurangan guru terjadi pada 25 provinsi, sedangkan 9 provinsi lainnya mengalami kelebihan guru. Provinsi Jawa Barat mengalami kekurangan guru sebanyak 64.053 orang, sedangkan di Provinsi Aceh mengalami kelebihan guru sebanyak 20.409 orang (Kemendikbud, 2016: 51).

Kekurangan guru pada suatu daerah berakibat pada terjadinya kelebihan jam mengajar yang dialami oleh guru di daerah tersebut. Sungguh ironis ketika terdapat banyak guru yang kekurangan jam mengajar akibat adanya penumpukan tenaga pendidik, sementara di daerah lain guru mengalami kelebihan jam mengajar akibat terbatasnya tenaga guru yang tersedia. Kelebihan jam mengajar yang terlalu banyak tentu berdampak pada efektivitas kegiatan pembelajaran, meskipun guru yang mengalami kelebihan jam mengajar tersebut merupakan guru profesional yang telah memiliki sertifikat pendidik. Hal ini mengingat tugas guru tidak hanya mengajar, tetapi juga menyiapkan bahan ajar melalui perencanaan yang matang serta memberikan penilaian untuk mengetahui ketercapaian hasil belajar pada masing-masing siswa serta tindak lanjut terhadap hasil belajar tersebut.

Sebagai ujung tombak peningkatan kualitas pendidikan, meski telah menyandang gelar profesional guru harus selalu meningkatkan kompetensi diri agar dapat menyesuaikan dan memenuhi berbagai tuntutan yang berkembang. 
Sebab perkembangan zaman akan selalu menuntut pembaruan dan penguasaan ilmu pengetahuan dan keterampilan yang lebih luas. Guru harus cerdas dan kreatif, proaktif, antisipatif. Dengan demikian guru diharapkan mampu mengembangkan diri secara berkesinambungan sehingga senantiasa memberikan dampak positif terhadap beraneka ragam aktivitas akademis termasuk dalam proses pembelajaran yang dilaksanakan. Penguasaan guru terhadap teknologi informasi memudahkan akses terhadap berbagai informasi mengenai perkembangan pendidikan, sehingga guru dapat mempelajari, mengadopsi ataupun mengimplementasikan kebijakan yang berlaku.

Peningkatan kompetensi secara terusmenerus salah satunya dapat dilakukan dengan meningkatkan pengalaman mengajar serta mengikuti kegiatan pendidikan dan pelatihan. Sebagian besar penelitian menunjukkan bahwa tingkat pendidikan mempunyai hubungan positif dengan kinerja (Irianto, 2013: 67). PPG Prajabatan sebagai upaya untuk mendorong kinerja dengan memaksimalkan kemampuan kerja calon guru profesional melalui program pendidikan. Praktik pengalaman lapangan (PPL) yang intensif dalam program PPG Prajabatan merupakan kegiatan untuk mengimplementasikan berbagai teori pembelajaran yang telah dipelajari selama mengikuti pendidikan guna memperoleh pengalaman mengajar secara riil. Dengan harapan guru profesional lulusan PPG Prajabatan ini memiliki kinerja yang baik. Di mana kinerja guru diukur oleh manajemen kelas guru, komitmen, dan tanggung jawab (Abd Hamid, Syed Hassan, \& Ismail, 2012: 98). Namun demikian, pelaksanaan PPG Prajabatan masih belum optimal ketika dalam pelaksanaanya masih menyamakan antara kompetensi awal peserta yang berasal dari lulusan kependidikan dan nonkependidikan di samping masih banyak kendala lain berkaitan dengan fasilitas dan sarana prasarana penyelenggaraan.

Masih belum optimalnya pengelolaan PPG Prajabatan menunjukkan masih lemahnya pengaturan hukum terhadap hal ini. Padahal, kegiatan pendidikan tersebut merupakan tonggak berdirinya proses pendidikan yang bermutu. Jika melihat pada program pendidikan di negara lain misalnya Malaysia yang telah terlebih dulu menyelenggarakan program profesi untuk menyiapkan guru berkualitas. Kualitas guru memang disiapkan dari awal sebelum guru tersebut ditempatkan pada instansi pendidikan. Kinerja dan kompetensi guru juga selalu dipantau untuk menjamin terselenggaranya pendidikan yang berkualitas.

Karena pentingnya kualitas guru dalam penyelenggaraan pendidikan yang berkualitas maka pemerintah dan seluruh elemen yang terkait harus bersungguh-sungguh dalam upaya pembenahan tata kelola guru berkaitan dengan penyelenggaraan PPG Prajabatan serta perlu adanya regulasi yang tepat. Oleh karena itu, substansi pendidikan profesi guru perlu diatur dengan tegas dalam Rancangan Undang-Undang tentang Guru.

\section{Penutup}

Pemenuhan kebutuhan guru profesional tidak dapat dilakukan serta merta. Masih perlu mekanisme terstruktur mulai dari pembentukan calon guru profesional melalui PPG Prajabatan serta sistem seleksi yang dilakukan secara profesional pula. PPG Prajabatan merupakan solusi jangka panjang dari keresahan terhadap lemahnya kualitas guru saat ini. Melalui PPG Prajabatan guru-yang pensiun nantinya dapat digantikan oleh guru yang telah memiliki kualifikasi dan kompetensi standar sesuai dengan SNP. Begitu pula dalam pemenuhan guru baik di pusat maupun di daerah mengingat pertumbuhan jumlah sekolah juga terus meningkat. Namun demikian pelaksanaan program PPG Prajabatan masih terus membutuhkan pembenahan, yaitu dari sisi kualitas LPTK, kualifikasi calon peserta didik, serta penyerapan lulusan.

Masih belum optimalnya pengelolaan pendidikan profesi guru, termasuk PPG Prajabatan menjadi hambatan dalam pemenuhan guru profesional. Revitalisasi LPTK menjadi kunci dalam perbaikan kualitas penyelenggaraan PPG Prajabatan yang berkualitas. Revitalisasi harus mencakup setiap aspek baik sarana dan prasarana, penyelenggaraan pendidikan serta jaminan mutu penyelenggaraan pendidikan. 
Selain itu peserta PPG Prajabatan dipilih melalui mekanisme yang tepat untuk menjamin bahwa calon guru yang dihasilkan nantinya benar-benar calon guru yang berkualitas, memiliki bakat, minat, keterampilan, serta panggilan jiwa untuk menjadi pengajar profesional. Kemudian lulusan PPG Prajabatan juga selayaknya diberikan peluang yang tinggi untuk segera ditempatkan pada institusi pendidikan yang sesuai. Berkaitan dengan hal tersebut, dalam rancangan UndangUndang tentang Guru yang sedang digagas DPR RI, substansi pendidikan guru mendapat perhatian khusus dengan harapan dapat menghasilkan regulasi yang dapat mendorong perbaikan mutu pendidikan secara efektif.

\section{DAFTAR PUSTAKA}

Abd Hamid, S. R., Syed Hassan, S. S., \& Ismail, N. H. (2012). Teaching Quality and Performance Among Experienced Teachers in Malaysia. Australian Journal of Teacher Education, 37(11). http://dx.doi.org/10.14221/ajte.2012v37n11.2.

Adzkia, A. (2018, Oktober 20). Kualitas Pendidikan Anak Indonesia Memprihatinkan. Diakses dari https://beritagar.id/artikel/berita/kualitaspendidikan-anak-indonesia-memprihatinkan, pada 7 Juni 2019.

Andina, E. (2018). Efektivitas Pengukuran Kompetensi guru. Jurnal Aspirasi, 9(2), 204 220. https://doi.org/https://doi.org/10.22212/ aspirasi.v7i1.1084

Andriani, E., Sumarmi, \& Astina, I. K. (2016). Peningkatan Kompetensi Pedagogik Guru. Jurnal Pendidikan, 1(11), 2106-2112.

Anwar, S. (2011). Studi Realitas tentang Kompetensi Kepribadian Guru Pendidikan Agama Islam Sekolah Menengah Atas. Jurnal Pendidikan Agama Islam -Ta'lim, 9(2), 145-159.

Direktorat Ketenagaan, Direktorat Jenderal Pendidikan Tinggi, Departemen Pendidikan Nasional. (2008). Panduan Pendidikan Profesi Guru Prajabatan. Jakarta: Direktorat Ketenagaan, Direktorat Jenderal Pendidikan Tinggi, Departemen Pendidikan Nasional.

Disas, E. P. (2017). Analisis kebijakan pendidikan mengenai pengembangan dan peningkatan profesi guru. Penelitian Pendidikan, 17(14), 158-166. Diakses dari http://ejournal.upi.edu/ index.php/JER/article/view/8251.
Dudung, A. (2018). Kompetensi Profesional Guru (Suatu Studi Meta-Analysis Disertasi Pascasarjana UNJ). JKKP: Jurnal Kesejahteraan Keluarga Dan Pendidikan, 05(01), 9-19. https://doi.org/doi. org/10.21009/JKKP.051.02.

Gaol, N.T.L. Membenahi kualitas pendidikan Indonesia. Diakses dari http://harian.analisadaily. com/opini/news/membenahi-kualitas pendidikan-indonesia/545175/2018/04/26, pada 7 Juni 2019.

Hasil Indonesian National Assesment Programme (INAP). (2016). Diakses dari https://puspendik. kemdikbud.go.id/inap-sd/, pada 7 Mei 2019.

Hosnan, (2016). Etika Profesi Pendidik Pembinaan dan pemantapan Kinerja Guru, Kepala Sekolah, serta Pengawas Sekolah. Bogor: Ghalia Indonesia.

Huda, M. (2017). Kompetensi Kepribadian Guru dan Motivasi Belajar Siswa. Jurnal Penelitian, 11(2), 237-266. Diakses dari http://journal. stainkudus.ac.id/index.php/jurnalPenelitian/ article/download/3170/pdf.

Irianto, A. (2013). Pendidikan sebagai Investasi dalam Pembangunan Suatu Bangsa (Cetakan kedua). Jakarta: Kencana Prenada Media Group.

Kemendikbud. (2016). Sumber Daya Manusia Pendidikan Dasar dan Menengah. Jakarta: Pusat Data dan Statistik Pendidikan dan Kebudayaan.

Kemendikbud. (2018, Desember 10). Kondisi dan alternatif Solusi Guru Honorer. Paparan Menteri Pendidikan dan Kebudayaan dalam Rapat Kerja Komisi X, Jakarta.

Lutfiyah, L. L., \& Winaryati, E. (2017). Pengaruh Kompetensi Sosial Guru Terhadap Hasil Belajar Siswa (di SMA Muhammadiyah 1 Semarang). Prosiding Seminar Nasional Pendidikan, Sains Dan Teknologi Fakultas Matematika dan Ilmu Pengetahuan Alam, Universitas Muhammadiyah Semarang Tahun 2017, 207-215.

Mahpudz, A. (2014). Analisis Kebijakan Peningkatan Kompetensi dan Profesionalisme Guru dalam Rangka Meningkatkan Mutu Penyelenggaraan Pendidikan Dasar di Kabupaten Sigi Provinsi Sulawesi Tengah. Jurnal Penelitian Kebijakan Pendidikan, 7(3), 1-18.

Martin, M. O., Mullis, I. V. S., Foy, P., \& Hooper, M. (2015). TIMSS 2015 International Results In Science. TIMSS \& PIRLS International Study Center Lynch School of Education, Boston College. Diakses dari http://timss2015.org/ download-center/.

Aspirasi Val 10 Na 1, Tuni 2019 
Mullis, I. V. S., Martin, M. O., Foy, P., \& Arora, A. (2015). TIMSS 2015 International Results in Mathematics. TIMSS \& PIRLS International Study Center Lynch School of Education, Boston College.https://doi.org/10.1002/yd.20038.

Musfah, J. (2015). Redesain Pendidikan Guru Teori, Kebijakan dan Praktik. Jakarta: Kencana.

Ningrum, E. (2012). Membangun Sinergi Pendidikan Akademik (S-1) dan Pendidikan Profesi Guru (PPG). Jurnal Pendidikan Geografi, 12(2).

Nuraidah. (2013). Kompetensi Profesional Guru untuk Meningkatkan Mutu Pembelajaran di Madrasah Ibtidaiyah Negeri Sei Agul Medan (Tesis) Program Pascasarjana IAIN Sumatera Utara.

OECD. (2016). Programme International Student Assessment (PISA), Country Note - Result from PISA 2015. Diakses dari https://www.oecd.org/ pisa/PISA-2015-Indonesia.pdf\%0D.

Puspendik Kemdikbud. Hasil UN SMP/MTs, SMA/ $M A$, dan $S M K$. Diakses dari https://puspendik. kemdikbud.go.id/hasil-un/, diakses 15 Mei 2019.

Sholikah. (2017). Analisis Undang-Undang No. 14 Tahun 2005 tentang Guru dan Dosen (Sebuah Kajian Kritis). Akademika, 11(14), 1-9.

Subkhan, E. (2016). Pendidikan Kritis (Kritik atas Praksis Neo-Liberalisasi dan Standarisasi Pendidikan. Yogyakarta: Ar-Ruzz Media.

Sudjatmiko, T. Revitalisasi Sarpras Pendidikan, Pemerintah Siapkan Rp2,7 T. Diakses dari https://krjogja.com/web/news/read/89533/ Revitalisasi_Sarpras_Pendidikan_Pemerintah Siapkan_Rp2_7_T, pada 20 Mei 2019.

Taufik, M. (2018, September 14). Anggaran Untuk Tingkatkan Mutu Guru. Kompas, hlm. 1-15.

Undang-Undang Republik Indonesia Nomor 14 Tahun 2005 tentang Guru dan Dosen (2005).

Undang-Undang Republik Indonesia Nomor 20 Tahun 2003 Tentang Sistem pendidikan Nasional (2003).

Yunus, S. (2018). Guru atau Kurikulum; Titik Urgen Kualitas Pendidikan Indonesia? Diakses dari https://kumparan.com/syarif-yunus/guru-ataukurikulum-titik-urgen-kualitas-pendidikanindonesia, pada 7 Juni 2019. 